УДК 94(47):002.2(091)"17/18”(045)

\title{
В.В. Календарова
}

\section{ВЕДОМСТВЕННАЯ И ОТРАСЛЕВАЯ ПЕРИОДИКА В ОБЩЕСТВЕННОЙ ЖИЗНИ НАЧАЛА ХІХ ВЕКА}

В статье на примере появившихся в России в конце XVIII - начале XIX в. отраслевых и ведомственных периодических изданий изучается вопрос о реакции общественности на появление газет и журналов, ориентированных на «серьёзное чтение». На основании анализа откликов читателей и критиков, а также тиражей ряда отраслевых и ведомственных журналов и газет и их дальнейшей судьбы (исчезновение или замена другим изданием) делаются выводы о том, что некоторые из подобных изданий сталкивались с трудностями в поиске «своего» читателя, однако отдельные периодические издания ведомственного характера были востребованы российским обществом начала XIX в. и имели коммерческий успех. Они заложили основы дальнейшего развития отраслевой и ведомственной периодической печати в России, получившей широкое распространение во второй половине XIX в.

Ключевые слова: история общественной жизни, история периодической печати, отраслевая периодика, ведомственная периодика, периодика XVIII в., периодика XIX в.

DOI: $10.35634 / 2412-9534-2021-31-4-710-720$

Первые отраслевые и ведомственные журналы появляются в России в конце XVIII — начале XIX в. Они издаются с переменным успехом, периодически закрываясь и сменяя друг друга, однако к середине XIX в. становятся неотъемлемой частью и литературной, и общественной жизни. В этой связи представляется актуальным определить место, занятое ими в период зарождения и становления в общем контексте русской журналистики начала XIX в., а также проследить, насколько это возможно, реакцию на появление этих изданий со стороны читающей публики.

История зарождения и развития русской периодической печати в XVIII - первой половине XIX в. достаточно хорошо освещена в исторической литературе $[2 ; 3 ; 17 ; 31]$. При этом, в связи с темой данного исследования, можно особенно выделить монографию А. И. Станько «Становление теоретических знаний о периодической печати в России», где автор прослеживает эволюцию взглядов деятелей русской журналистики XVIII - начала XIX в. на конкретные задачи и функции своего «ремесла» [45]. Полагаем, что именно теоретические искания русской журналистики начала XIX в. наиболее отчётливо отражают отличия новых видов периодической печати, ведомственных и отраслевых изданий, от остальной массы русских журналов этого периода.

Так, редактор первого русского журнала «Ежемесячные сочинения, к пользе и увеселению служащие» (1755) Г. Миллер считал своей главной задачей привлечение внимания к журналу как можно большего числа читателей. Проповедуя идеи «энциклопедичности и массовости», в структуре своего издания он чётко разделял научные (научно-популярные) и литературные материалы, реализуя на практике формулу, звучавшую в названии его журнала - «польза и увеселение». В дальнейшем, на весь период XVIII и начала XIX в. эта формула стала своеобразным девизом русской журналистики. Конечно, разные её деятели по-разному трактовали и первое, и второе понятия. Например, для известного издателя и общественного деятеля екатерининской эпохи Н. И. Новикова «польза» журналистики заключена в её служении исправлению нравов с помощью сатиры и критики. Его царственный оппонент, императрица Екатерины II, инспирировавшая в противовес сатирическим изданиям Новикова журнал «Всякая всячина», советовала журналистам ограничиваться увеселением читателей, а если и высмеивать недостатки для пользы дела, то, по крайней мере, «из человеколюбия» не называть при этом конкретных лиц. В русле развития формулы «польза и увеселение», «полезное и приятное» можно рассматривать и «Московский Журнал» Н. М. Карамзина (издание 1791-1792 гг.). Средствами периодической печати Н. М. Карамзин, в молодости известный республиканскими убеждениями, которые позже сменил на довольно консервативные взгляды [16, с. 144], стремился развивать в людях добрые побуждения, заменив воздействие на разум читателей воздействием на чувства. Те же самые традиции, по сути, продолжал и знаменитый «Вестник Европы» - второе периодическое издание Н. М. Карамзина (основан в 1802 г.). Введённый им в журнал отдел политики должен 
был составлять одновременно и занимательное, и полезное чтение для читателей, которые не имеют возможности самостоятельно следить за иностранной периодикой [45, с. 20-67].

Вывод А. И. Станько о том, что своей основной задачей представители русской журналистики рассматриваемого периода видели служение «пользе и увеселению» читающей публики, представляется справедливым лишь отчасти. Это утверждение напрямую можно отнести только к некоторым периодическим изданиям, которые принято называть передовыми. Конечно, во второй половине XVIII начале XIX в., как и во все времена, были издания, вполне удовлетворявшиеся второй частью формулы («увеселение») или же ставившие её на первое место. Такими изданиями были, например, альманахи, история которых начинается с «Аглаи» Карамзина (издание основано в 1794 г.). Как пишет В. Г. Березина, «отличительной чертой альманахов Карамзина и карамзинистов являлось то, что они давали лёгкое, приятное, занимательное чтение и рассчитаны были, прежде всего, на признание "прекрасных читательниц"». Традицию светских альманахов впоследствии изменили декабристы, «создавшие свой тип альманаха, призванный воспитывать читателя в гражданском духе» [2, с. 25]. При этом лёгкие, исключительно увеселительные альманахи, как и журналы, издавались и впоследствии.

В то же время к последней четверти XVIII в. относится, хотя ещё и недостаточно чёткое, но очевидно наметившееся, разделение отечественной периодической печати по типам: начинают выходить театральные, литературно-критические («Московский Журнал»), критико-библиографические, исторические, медицинские, специальные детские и дамские журналы. В это время, знаменуя отход от формулы «польза и увеселение», появляется и ряд чисто специализированных изданий, в которых по определению не могло присутствовать ничего, что могло бы служить «увеселению» публики. Так, в 1791-1792 гг. В. В. Новиков предпринял попытку издания первого юридически направленного журнала. Им стал «Театр судоведения или Чтение для судей и всех любителей юриспруденции», который ставил целью широкое распространение юридических знаний. Этот журнал использовал для привлечения читательского внимания броские заголовки, однако благородной миссией его издателя были просвещение публики и борьба за справедливость, что выражалось в изложении собственных взглядов на теорию права в исторической перспективе [12, с. 11]. Можно предположить, что возникновение отраслевых периодических органов свидетельствовало о том, что в российском обществе появились люди, способные приняться за такие издания, считающие их целесообразными, а значит, по всей видимости, рассчитывающие на то, что эти издания будут приняты публикой.

Однако, по мнению А. Ф. Горобца, первые юридические издания были обречены на низкий читательский спрос, связанный с отсутствием в обществе того слоя, который мог бы проявить к ним истинный интерес. Аргументом к этому утверждению служат обстоятельства издания следующих юридических журналов, появившихся уже в начале XIX в. Так, в 1812 г. надворный советник И. Беллинсгаузен предпринял издание второго в истории российской журналистики юридического периодического органа, «Журнала правоведения», однако его выпуск был прекращён сразу после выхода первого номера из-за недостатка подписчиков. Та же участь постигла и частное издание коллежского советника И. М. Наумова - «Журнал Дома практического правоведения по предмету образования стряпчества» (1813 г.). Тем не менее А. Ф. Горобец полагает, что названные журналы опередили запросы общества, но способствовали его интеллектуальному и культурному развитию, а также заложили основы отраслевой юридической журналистики, которая получила развитие позже, примерно с 1840-х - 1850-х гг. [12, с. 12-13]. Их влияние прослеживается в «Юридических записках» российского правоведа П. Г. Редкина, пытавшегося посредством издания журнала «содействовать благим видам правительства в деле отечественной юриспруденции, в распространении юридических познаний в нашем отечестве, в ускорении сознательного чувства законности и долга» [13, с. 604], а также в «Юридическом вестнике» Н. В. Калачова, «Юридическом журнале» П. А. Салманова, и, наконец, в ведомственном «Журнале Министерства юстиции». При этом ещё в 1841 г. основатель «Юридических записок» П. Г. Редкин, считая издание сугубо отраслевого юридического журнала преждевременным, т. к. оно «мало кем будет замечено и оценено», предпочёл придать своему детищу облик «журнала научного и литературного» [12, с. 14].

В начале XIX в. начали издаваться также военные периодические издания, однако ведомственные военные журналы печатались небольшими тиражами (например, «Военный журнал» военноучётного комитета Главного штаба имел тираж 500 экз.), а неофициальные военные журналы испытывали трудности и быстро закрывались в связи с цензурными ограничениями (в качестве примера можно привести «Военный журнал» Общества военных людей, 1817-1819 гг.) [4, с. 26]. 
Начиная с последней четверти XVIII в., издание «полезной периодики» время от времени предпринималось не только в российских столицах, но и в провинции. Так, пионером губернской периодической печати стали «Тамбовские известия», издававшиеся в 1788 г. Г. Р. Державиным, ставившим целью обнародование касающихся губернии распоряжений и другие полезные обществу публикации. Однако, по мнению В. В. Шевцова, успеху газеты также помешало отсутствие достаточной прослойки образованных и заинтересованных людей. Несколько более удачным опытом провинциальной печати стали основанные в 1811 г. «Казанские известия», издание которых было поддержано Казанским университетом [47, с. 26]. В 1819 г. по инициативе командующего Отдельного грузинского корпуса А. П. Ермолова в Грузии предпринимается издание «Грузинской газеты», выходившей на национальном языке и включавшей в себя публикацию сообщений о награждениях, правительственные распоряжения относительно края, статьи о новых изобретениях и т. д. Коллектив издателей рассчитывал набрать для своей газеты около 500 подписчиков, но эти планы выполнить не удалось. На основании выявленных сложностей с обеспечением газеты подписчиками, исследователь грузинской периодической печати Д. Л. Ватейшвили полагает, что широкие слои населения не были подготовлены к такому нововведению. Несмотря на все усилия число читателей «Грузинской газеты» постоянно уменьшалось, а в 1822 г. она собрала в Тифлисе только 19 подписчиков на сумму 57 руб., что привело в итоге к её закрытию [7, с. 364-372]. Более удачным опытом издания газеты, отвечавшей «видам правительства» в пограничном регионе, стали «Тифлисские ведомости», выходившие позже на русском языке (1828-1832) [7, с. 385].

Из сказанного выше можно сделать вывод, что многие серьёзные периодические издания конца XVIII - начала XIX в., не стремившиеся развлекать и увеселять читающую публику, не могли похвастаться коммерческим успехом. Однако были в это время и периодические печатные органы, которые, поставив основной целью служение общественной пользе, смогли занять прочное место в журналистике начала XIX в. Это ведомственные журналы, которые издавались в течение долгого времени и впоследствии сменились новыми изданиями того же направления и той же ведомственной принадлежности. Речь идёт, в первую очередь, о «Периодическом сочинении об успехах народного просвещения» (орган Министерства народного просвещения, издавался в 1803-1819 гг.) и «СанктПетербургском журнале» (печатный орган Министерства внутренних дел, издавался в 1804-1809 гг.). Данные издания, возникшие в начальный период царствования Александра I на волне идей правительственного либерализма, ставили целью внести гласность в деятельность правительственных органов, а также пропагандировать определённые общественные идеи, связанные с реформаторскими планами молодого императора $[19$, с. 54-55]. Журналы по определению исключали возможность служить «увеселению» публики, оставляя своей миссией только служение общественной «пользе». Так, в «Объявлении» о начале издания «Санкт-Петербургского Журнала», помещённом в «СанктПетербургских ведомостях», его издатели, в частности, утверждали, что новый печатный орган имеет целью исправить существовавшую прежде ситуацию, в которой было затруднительно «приобресть некоторое понятие о делах вне службы, чтоб со временем приготовить себя к ней» [35].

Редактором «Санкт-Петербургского журнала», предположительно, был Михаил Никитич Баккаревич, бывший преподаватель словесности в Московском университетском благородном пансионе, с 1802 г. перешедший на службу в Санкт-Петербург в только что созданное Министерство внутренних дел $[34$, ф. 1286, оп. 1 , д. 102, л. 24об, 42]. Редактором «Периодического сочинения об успехах народного просвещения» называют либо акад. Н. Я. Озерецковского, либо акад. Н. И. Фусса (оба члены Главного правления училищ Министерства народного просвещения) [46]. По сей день публикации этих журналов остаются ценным источником для изучения правительственных идей начала XIX в., вопросов регулирования положения сословий в России, организации поселения в империи иностранных колонистов, традиций русской благотворительности, развития соляных промыслов и соляной торговли, вопросов организации армии, органов управления на местах $[18$, с. 20], развития системы образования в России [46].

То, что специализированные журналы не исчезли в скором времени, а продолжали достаточно успешно развиваться, говорит и о том, что определённая часть просвещённой публики воспринимала и приветствовала такие издания. Безусловно, наиболее ярко об успехе того или иного издания в глазах публики свидетельствует число его читателей, однако документальных данных о числе подписчиков многих специализированных и ведомственных изданий нет, вследствие отсутствия сохранившихся ар- 
хивов этих периодических органов. Проанализировать реакцию читающей публики на появление первых отраслевых и ведомственных журналов возможно в основном лишь по косвенным данным.

Например, о значительном успехе «Санкт-Петербургского Журнала», периодического органа МВД, свидетельствуют слова из донесения сардинского посланника Ж. де Местра, который 25 февраля 1805 г. сообщил королю Сардинии Виктору-Эммануилу I о том, что в Петербурге министр внутренних дел граф Кочубей «издаёт Русский Журнал, в котором печатает все записки, представленные императору касательно различных отраслей управления и все письма Его Величества ко всем губернаторам <... . Для того, чтобы поставить на ноги этот журнал, Государь назначил 6000 рублей. На следующий год журнал не только окупился, но и дал 13000 рублей прибыли» в первый же год его издания [30, с. 67]. Эта информация даёт возможность вычислить приблизительный тираж издания. То, что данный журнал окупил 6000 руб., потраченных на его издание и принёс ещё 13000 руб. прибыли доказывает, что общий доход от его продажи составил 19000 руб. Из публикации в газете «Санкт-Петербургские ведомости» (№ 92 за 1803 г.) следует, что стоимость годовой подписки на «Санкт-Петербургский Журнал» в первый год его издания составляла 12 руб. в Петербурге и 15 руб. при пересылке в другие города [35]. В последующие годы стоимость подписки не менялась. Получается, что в 1804 г. было продано минимум 1270 комплектов журнала (при стоимости подписки 15 руб.). При учёте того, что значительная часть тиража, вероятнее всего, продавалась в столице, можно предположить, что реальное количество подписчиков журнала могло доходить до $1500-$ цифра, более чем впечатляющая (например, успешнейший проект Н. М. Карамзина «Вестник Европы» собрал в Москве в 1802 г. свыше 1200 подписчиков). Успех «Санкт-Петербургского Журнала» у читающей публики подтверждают и сами его издатели. Так, в «Объявлении», помещённом в ноябре 1804 г. в «Санкт-Петербургских ведомостях», они сообщают, что «ободрённые вниманием публики к изданию их <..> приемлют на себя продолжать оное и в следующем году тем же порядком» [36]. Аналогичное «Объявление» помещено и в последнем номере самого «Санкт-Петербургского Журнала» за 1804 г. [40, с. 140]. Объявления о том, что очередная книжка «Санкт-Петербургского Журнала» уже «отпечатана и раздаётся в лавках купца Ивана Глазунова» в «Санкт-Петербургских ведомостях» печатались практически ежемесячно с указанием цены на подписку [37-39].

Ещё одним свидетельством интереса читающей публики к «Санкт-Петербургскому Журналу» можно считать активное участие в нём читателей, откликавшихся на призыв присылать свои сочинения и переводы в соответствующие профилю издания. Среди присланных читателями материалов можно назвать, например, статьи «О тюрьмах в Филадельфии» с сопроводительным письмом к издателям «от неизвестного автора» [26], «Примечания о продаже людей в рекруты» [32], «Некоторые замечания о подложных увечьях, в отбывательство от рекрутства чинимых» [25], «Мысли гражданина» [24], «Сведения, выписанные из российских летописцев» [41] и др.

Перспективным направлением исследований представляется поиск отзывов о «полезных» ведомственных и специализированных журналах в мемуарах или переписке того времени. Пока единственный отзыв современника о «Санкт-Петербургском Журнале», которым располагают исследователи, содержится в письмах будущего митрополита Евгения (Болховитинова) к его «воронежскому приятелю» В. И. Македонцу от декабря 1804 г.: «Читаете ли вы журнал Внутренних дел министра, издаваемый под именем “Санкт-Петербургский Журнал”? Для меня это кажется прекраснейшая книга. А особливо отчёт за 1803 год. Книга сия есть во всех губернских правлениях...» [8, с. 841]. На основании этого свидетельства исследователь общественного движения в России А. Н. Пыпин делает вывод о том, что образованные люди высоко оценили нововведение министерства В. П. Кочубея [33, с. 124], с чем трудно не согласиться. Письмо митрополита Евгения (Болховитинова), написанное в Новгороде в период проживания там автора послания, также доказывает, что «СанктПетербургский Журнал» был востребован не только в столицах, но и в провинции.

Стоит упомянуть и ещё один отзыв о «Санкт-Петербургском Журнале», появившийся в период, не слишком отдалённый от времени его издания. Речь идёт о реплике Журнального Сыщика, автора «Обозрения русских газет и журналов...», напечатанного в 1827 г. в одном из наиболее прогрессивных печатных органов первой половины XIX в., журнале «Московский Телеграф». В основном в «Обозрении...» перечисляются названия российских периодических органов с указанием дат их издания и имён редакторов; более подробно автор статьи комментирует только те из них, которые, по его мнению, стоит считать своеобразными вехами в истории русской журналистики. Название «СанктПетербургского Журнала» Сыщик сопровождает репликой: «отличный журнал» [27, с. 124]. Предла- 
гая собственную концепцию истории развития российской журналистики, автор «Обозрения...» довольно презрительно отзывающийся о «лёгких журналах», высоко ценит издания Н. М. Карамзина и его последователей: «Другое, высшее поколение журналов, явилось собственно из "Московского Журнала" и "Вестника Европы". Словесность, науки, а впоследствии критика и, наконец, библиография составляли и составляют их сущность» [28, с. 185].

Чтобы понять, кто именно дал «Санкт-Петербургскому Журналу» столь высокую оценку, остановимся на истории выяснения авторства упомянутой статьи. В 1956 г. исследователь истории русской периодической печати П. Н. Берков писал, что вопрос о расшифровке псевдонима «Журнальный Сыщик» «имеет длинную историю и до сих пор не считается решённым» [5, с. 10]. При этом чаще всего псевдоним «Журнальный Сыщик» приписывался известному поэту и литературному критику Петру Андреевичу Вяземскому, на основании его собственных воспоминаний об участии в издании журнала «Московский Телеграф» [23]. Однако, по утверждению самого П. А. Вяземского, случалось, что «сам издатель Телеграфа и другие, тайные по особым поручениям чиновники его, подписывались под мою руку» [9, с. 258-259]. Исследователями Л. Н. Майковым, В. Г. Березиной и М. И. Гиллельсоном выдвигалось предположение о том, что автором «Обозрения...» мог быть редактор «Московского Телеграфа» Н. А. Полевой $[22$, с. $369 ; 1$, с. 92-109; 11, с. 130]. В монографии, посвящённой П. А. Вяземскому, М. И. Гиллельсон также писал, что окончательное подтверждение этому ему удалось обнаружить в архивах сотрудника «Московского Телеграфа» С. Д. Полторацкого в ГПБ и БЛ (ныне - РНБ и РГБ), без указания того, в чём именно состоит это подтверждение [11, с. 130]. В одной из рукописей С. Д. Полторацкого, хранящейся в РГБ, действительно, удалось найти утверждение о том, что авторство «Обозрения...» принадлежит Н. А. Полевому [29, ф. 233, оп. 5, д. 6, л. 1-1об]. Тем не менее, есть обстоятельства, которые позволяют усомниться в сказанном. В 1828 г. в «Московском Телеграфе» была помещена статья-рецензия «Дополнения и поправки к истории русских газет и журналов», разбирающая ошибки и неточности, допущенные в «Обозрении...». Статья сопровождена дополнительным примечанием от издателя (Н. А. Полевого) [14, с. 235] и подписана инициалами «С. П-ий», которые, очевидно, следует расшифровать как «С. Полторацкий». Автор данной статьи также высоко отзывается о «Санкт-Петербургском Журнале»: «весьма замечательный журнал» [14, с. 232-233]. В то же время, в упомянутой выше рукописи С. Д. Полторацкий отказывается от авторства данной рецензии. Он утверждает, что, хотя «Дополнения...» и опубликованы в журнале как «...будто бы "Письмо к издателю “Телеграфа" от С. Полторацкого, но это не от меня письмо, и моим псевдонимом вздумалось подписаться самому Полевому» [29, ф. 233, оп. 5, д. 6, л. 1-1об]. Ситуация, в которой Н. А. Полевой был и автором «Обозрения...», и критических замечаний на него («Дополнений»), представляется пусть и не невозможной, но всё же не слишком вероятной. В связи с вышесказанным можно утверждать, что вопрос об авторстве «Обозрения...», а также «Дополнений и поправок...» к нему, по-прежнему остаётся открытым. Помимо П. А. Вяземского и Н. А. Полевого, осуществлявших, по словам М. И. Гиллельсона, идейное руководство «Московским Телеграфом» сообща, так, что их «сотрудничество <...> было столь тесным, что вряд ли представится возможность полностью разграничить их авторство» [11, с. 151], автором «Обозрения...» мог быть и брат Н. А. Полевого Кс. А. Полевой, тоже активно сотрудничавший в «Московском Телеграфе». Тот же М. И. Гиллельсон утверждает, что ряд статей этого журнала за подписью «Журнальный Сыщик» писались именно Кс. А. Полевым [10, с. 322].

Представляется, что отдельного внимания заслуживают также оценки «Санкт-Петербургского Журнала», данные редакторами последующих печатных органов МВД. Так, например, в 1830 г., в «Объявлении», открывающем второй год издания «Журнала Министерства внутренних дел», его издатели высоко оценили периодические органы своих предшественников - «Санкт-Петербургский журнал» и «Северную Почту»: «Сколь ни различны планы обоих сих изданий, но каждое из них принесло свою пользу. Особенно сказать сие можно о "Санкт-Петербургском Журнале”. Многие из служащих теперь с похвалою чиновников почерпнули в нём первые правильные о делах правительственных понятия» [15]. Более скептически об успехах «Санкт-Петербургского журнала» в 1859 г. отозвался новый редактор «Журнала МВД» Н. В. Варадинов, вступивший на эту должность в 1855 г. Ещё в 1830-е гг. столкнувшись с утратой читательского интереса [6, с. 18-19], журнал МВД не преодолел кризис и в 1850 -е гг. Тем не менее в связи с 30-летним юбилеем «Журнала МВД» (1829-1859) была издана небольшая монография о нём. Анализируя на её страницах низкий интерес читателей к периодическому органу МВД, Н. В. Варадинов утверждает, что журнал «...не доставлял удовольствия минутному любо- 
пытству, которое публика, непривыкшая к серьёзному чтению, находила в ежедневных газетах, <...> он не имел общепонятного энциклопедического содержания <...>, он не допускал ни критики, ни полемики <..> его нельзя было читать в минуты отдохновения, а было необходимо заниматься им как делом, как особенным трудом, к чему большинство не приготовилось ещё» [6, с. 18-19]. Выводы о причинах неуспеха у публики «Журнала МВД» Н. В. Варадинов механически переносит и на «СанктПетербургский Журнал», критикуя отсутствие в нём понятных публике энциклопедических статей и отрывочность публикуемых сведений о внутреннем управлении, к которым, по его мнению, необходимо «присоединять соответствующие предшествующие узаконения» [6, с. 20-21].

В противовес мнению Н. В. Варадинова отметим, что не имеется никаких доказательств того, что причиной прекращения издания «Санкт-Петербургского Журнала» было падение читательского спроса. Напротив, немалое число подписчиков «Северной Почты», сменившей в МВД «СанктПетербургский Журнала», свидетельствует о том, что министерские издания пользовались успехом у публики на протяжении всей первой четверти XIX в. Так, в 1809-1819 гг. «Северная Почта» собирала от 1762 до 5418 подписчиков, а в 1810 г., включая последние месяцы 1809 г., у газеты было 1762 подписанных читателя [42]. Таким образом, едва ли можно согласиться с утверждением Н. В. Варадинова, что издание «Санкт-Петербургского Журнала» было прекращено «за неимением средств» вследствие потери читательского интереса. Очевидно, что закрытие журнала в 1809 г. было связано с началом выхода газеты «Северная Почта», которая стала выражением изменившегося курса Министерства внутренних дел после назначения на пост главы министерства О. П. Козодавлева [48, с. 87]. Газета Министерства внутренних дел, просуществовавшая в течение 10 лет, знакомила читающую публику не только с текущим положением дел по части Министерства внутренних дел и публиковала экономические статьи, но и вела активную просветительскую политику, например, знакомила читателей с парламентскими дискуссиями в европейских странах, публиковала материалы, касавшиеся исторического опыта цензурирования печатных изданий [44]. Газета публиковала статьи, посвящённые выдающимся российским писателям, помещала обстоятельные обзоры специализированной и энциклопедической периодики [20, с. 48]. Положительную оценку министерской газеты, данную основателем русской «полезной» журналистики Н. М. Карамзиным, приводит Е. М. Сонина: обращаясь к литератору И. М. Дмитриеву, М. Н. Карамзин просит его выразить благодарность издателю «Северной Почты» за статью о грамотах Кенигсбергского архива [43]. Газета «Северная Почта» издавалась при Министерстве внутренних дел до 1819 г. включительно. В 1829 г. при ведомстве по инициативе нового министра внутренних дел А. А. Закревского началось издание «Журнала министерства внутренних дел», публиковавшего, помимо официальных документов, статистические материалы и статьи по вопросам истории, культуры, краеведения и здравоохранения [21, с. 24].

На основании вышесказанного можно сделать следующие выводы. Несмотря на то что некоторые отраслевые, специализированные периодические издания конца XVIII - начала XIX в. испытывали серьёзные сложности, связанные с низким читательским интересом, есть несколько фактов, свидетельствующих о том, что периодические издания, нацеленные на серьёзное чтение, были востребованы российским обществом начала XIX в. Во-первых, специализированные и ведомственные журналы не исчезли в скором времени, а продолжали достаточно успешно развиваться - это говорит о том, что значимая часть просвещённой публики воспринимала и приветствовала такие издания. С 1804 г. не переставали издаваться периодические печатные органы МВД («Санкт-Петербургский Журнал», «Северная Почта», «Журнал Министерства внутренних дел»). «Периодическое сочинение об успехах народного просвещения» - печатный орган Министерства народного просвещения, прекратив издание в 1819 г., возродился уже в 1821 г. как «Журнал Департамента народного просвещения». Во второй четверти ХIX в. появляются также свои печатные органы и у ряда других министерств. Несмотря на то, что «Санкт-Петербургский Журнал» МВД (1804-1809) был нацелен исключительно на серьёзное чтение и не содержал никаких занимательных или развлекательных материалов, рассчитанных на массового читателя, приведённые свидетельства доказывают, что он пользовался успехом у читающей публики и имел коммерческий успех. Всё это свидетельствует о том, что, в российском обществе первой четверти XIX в. нашлось достаточное количество людей, по достоинству оценивших опыт серьёзного чтения периодических изданий. 


\section{СПИСОК ИСТОЧНИКОВ И ЛИТЕРАТУРЫ}

1. Березина В. Г. Н. А. Полевой в «Московском Телеграфе» // Учёные записки ЛГУ. Серия филологических наук. Л., 1954. Вып. 20. № 173. С. 92-109.

2. Березина В. Г. Русская журналистика первой четверти ХІХ века. Л.: Изд-во Ленингр. ун-та, 1965.90 с.

3. Березина В. Г. Русская журналистика второй четверти XIX века. (1826-1839). Л.: Изд-во Ленингр. ун-та, 1965. $102 \mathrm{c}$

4. Белогуров С. Б. История военной периодической печати в России (XIX — начало ХХ вв.): автореф. дис. ... докт. ист. наук. М.: [б. и.], 1997. 52 с.

5. Берков П. Н. О библиографических трудах по русской периодической печати: Вступительная статья // Машкова М. В., Сокурова М. В. Общие библиографии русских периодических изданий 1703-1954 гг. и материалы по русской периодической печати: Аннотированный указатель. Л.: [б. и.], 1956. С. 5-34.

6. Варадинов Н. В. Тридцатилетие «Журнала Министерства внутренних дел» СПб.: [б. и.], 1859. 104 с.

7. Ватейшвили Д. Л. Грузия и европейские страны: очерки истории взаимоотношений, XIII-XIX вв.: в 3 т. T. 3: Грузия и Россия, XVIII-XIX вв.: в 4 кн. Кн. 3. М.: Ин-т рос. истории РАН, 2006. 775 с.

8. Выдержки из дружеских писем Евгения (будущего митрополита Киевского) к воронежскому приятелю его Василию Игнатьевичу Македонцу // Русский Архив. 1870. Вып. 4-5. С. 769-870.

9. Вяземский П. А. Письма из Парижа // Полн. собр. соч. князя П. А. Вяземского. Т. 1. СПб., 1878. С. $219-259$.

10. Гиллельсон М. И. Указатель статей и других прозаических произведений П. А. Вяземского с 1808 по 1837 г. // Учёные записки Горьков. ун-та. Серия историко-филологическая. Горький, 1963. Вып. 58. С. $113-332$.

11. Гиллельсон М. И. П. А. Вяземский - жизнь и творчество. Л.: Наука. Ленингр. отд-ние, 1969. 391 с.

12. Горобеи А. Ф. Отечественные юридические журналы XIX века (эволюция и характерные особенности): автореф. дис... канд. филол. наук. Краснодар: [б. и.], 2012. 27 с.

13. Горобеи $A . \Phi$. Первые юридические периодические издания журнального типа // Мир науки, культуры, образования. 2020. № 2 (81). С. 604-606.

14. Дополнения и поправки к истории русских газет и журналов: Письмо к Издателю «Телеграфа»// Московский Телеграф. 1928. Ч. XXIV. № 22. С. 225-235.

15. Журнал Министерства внутренних дел. 1830. № 1.

16. Идеологии и генезис ценностей современного общества. СПб.: Изд-во РХГА, 2016. 352 с.

17. История русской журналистики XVIII-XIX вв. / под ред. А. В. Западова. М.: Высшая школа, 1973.521 с.

18. Календарова В. В. Возникновение ведомственной периодики в России в начале ХІХ века. Первые министерские журналы: автореф. дис. ... канд. ист. наук. СПб.: [б. и.], 2000. 26 с.

19. Календарова В. В. Либеральные идеи в России в начале XIX века: попытка правительственной пропаганды (опыт количественного анализа содержания первых министерских журналов) // Источник. Историк. История. Сб. науч. работ. Вып. 1. СПб.: [б. и.], 2001. С. 52-72.

20. Канадзава Т. Отзывы о «Детском музеуме» в газете «Северная Почта или Новая Санкт-Петербургская газета» // Текстология и историко-литературный процесс. V Междунар. конф. молодых исследователей: сб. ст. М.: Буки-Веди, 2017. С. 48-57.

21. Красножон О. В. Печать Министерства внутренних дел как средство обеспечения эффективной деятельности ведомства (результаты ретроспективного анализа) // Вестн. СПб. ун-та МВД. 2017. № 1 (73). С. 23 -27.

22. Майков Л. Н. Очерки из истории русской литературы XVII и XVIII столетий. СПб.: [б. и.], 1889. 434 с.

23. Масанов И. Ф. Словарь псевдонимов русских писателей, ученых и общественных деятелей. Москва: Изд-во Всесоюз. книжной палаты, 1956. Т. 1. 442 с.

24. Мысли гражданина // Санкт-Петербургский Журнал. 1806. № 1. С. 95-98.

25. Некоторые замечания о подложных увечьях, в отбывательство от рекрутства чинимых // СанктПетербургский Журнал. 1804. № 11. С. 140-143.

26. О тюрьмах в Филадельфии // Санкт-Петербургский Журнал. 1804. № 10. С. 115-139.

27. Обозрение русских газет и журналов с самого начала их до 1828 года // Московский Телеграф. 1827. Ч. XVIII. №№ 23. С. 123-148.

28. Обозрение русских газет и журналов... (продолжение) // Московский Телеграф. Ч. XVIII. № 24. С. $179-195$.

29. Отдел рукописей Российской Государственной Библиотеки (ОР РГБ). Ф. 233. С. Д. Полторацкий.

30. Письма из Петербурга в Италию графа Жозефа де Местра // Русский Архив. 1871. № 6. С. 53-149.

31. Предтеченский A. В. Экономические журналы первой четверти XIX в. // Общественная мысль в России ХІХ в. Л.: Наука, 1986. С. 7-18.

32. Примечания о продаже людей в рекруты // Санкт-Петербургский Журнал. 1804. № 10. С. 119-122.

33. Пыпин А. Н. Общественное движение в России при Александре I. 4-е. изд. Пг., 1918. 587 с.

34. Российский государственный исторический архив (РГИА). Ф. 1286. Департамент полиции исполнительной.

35. Санкт-Петербургские ведомости. 1803. № 92.

36. Санкт-Петербургские ведомости. 1804. № 95.

37. Санкт-Петербургские ведомости. 1808. № 53. 
38. Санкт-Петербургские ведомости. 1808. № 66.

39. Санкт-Петербургские ведомости. 1808. № 95.

40. Санкт-Петербургский Журнал. 1804. № 12. С. 140.

41. Сведения, выписанные из российских летописцев // Санкт-Петербургский журнал. 1809. № 5. С. 63-84.

42. Северная Почта или Новая Санкт-Петербургская газета. 1819. № 105.

43. Сонина E. C. Н. М. Карамзин в «Северной почте или Новой Санкт-Петербургской газете» // Русская литература и журналистика в движении времени. 2018. № 1. С. 25-37.

44. Сонина E. C. «Сколь можно более свободы»: «Северная Почта, или Новая Санкт-Петербургская газета» о цензуре // Цензура в России: история и современность: сб. науч. тр. СПб.: Российская нац. б-ка, 2017. C. 359-371.

45. Станько А. И. Становление теоретических знаний о периодической печати в России (XVIII в. - 60-е гг. ХІХ в.). Ростов-н/Д: Изд-во Ростов. ун-та, 1986. 206 с.

46. Феребов A. Н. К вопросу о хронологии сводных статистических данных, опубликованных в 23-ем номере «Периодического сочинения о успехах народного просвещения». Предварительные итоги исследования // URL: https://moluch.ru/conf/hist/archive/54/2491/ (дата обращения: 31.03.2021).

47. Шевцов B. В. Формирование и развитие губернской официальной прессы Сибири во второй половине ХІХ начале XX века: автореф. дис. Де... д-ра ист. наук. Томск: [б. и.], 2014. 51 с.

48. Янченко И. Л., Токмачева А. Ю. Ведомственная периодическая печать в системе Министерства внутренних дел Российской империи (дореформенный период XIX в.) // Труды Академии управления МВД России. 2018. № 4. С. 86-92.

Поступила в редакцию 23.09.2020

Календарова Виктория Владимировна, кандидат исторических наук,

доцент кафедры истории цивилизации, физической культуры и спорта, философии и социологии

ФГБОУ ВО «Российский государственный университет физической культуры, спорта,

молодёжи и туризма»

105122, Россия, г. Москва, Сиреневый бульвар, 4

E-mail: vkalendarova@mail.ru

\section{V. Kalendarova \\ DEPARTMENTAL AND BRANCH PERIODICALS IN PUBLIC LIFE AT THE BEGINNING OF XIX CENTURY}

DOI: $10.35634 / 2412-9534-2021-31-4-710-720$

The article examines the question of the public reaction to the appearance of newspapers and magazines focused on the "serious reading", using the example of branch and departmental periodicals that appeared in Russia in the late 18th early 19th centuries. Based on the analysis of readers' and critics' responses, as well as of circulation of several studied magazines and newspapers and of their future (disappearance or replacement by another periodical), it is concluded that some of these magazines and newspapers faced difficulties in finding "their own" readers. However, there was a demand for some other public administration periodicals in the Russian society at the beginning of the 19th century, which leaded to their commercial success. These periodicals have laid the foundations for the further development of branch and departmental periodical press in Russia, the wide development of this type of press being observed in the second half of the 19th century.

Keywords: history of public life, history of periodicals, branch periodical press, departmental periodical press, periodicals of the 18th century, periodicals of the 19th century.

\section{REFERENCES}

1. Berezina V. G. N. A. Polevoj v "Moskovskom Telegrafe" [N. A. Polevoy at "Moscow Telegraph"]. Uchenye zapiski LGU. Seriya filologicheskih nauk [Scientific Notes of the LSU. Series of philological sciences], Leningrad, 1954, issue 20, no. 173, pp. 92-109. (In Russian).

2. Berezina $V$. G. Russkaya zhurnalistika pervoj chetverti XIX veka [Russian journalism of the first quarter of the 19th century]. Leningrad, Leningrad University Press, 1965, 90 p. (In Russian).

3. Berezina $V$. G. Russkaya zhurnalistika vtoroj chetverti XIX veka. (1826-1839) [Russian journalism of the second quarter of the 19th century. (1826-1839)]. Leningrad, Leningrad University Press, 1965, 102 p. (In Russian). 
4. Belogurov S. B. Istoriya voennoj periodicheskoj pechati v Rossii (XIX — nachalo XX vv.) [History of military periodicals in Russia (19 $9^{\text {th }}$ - early 20th centuries)]: avtoref. dis..... d-r hist. sciences, Moscow, [n. a.], 1997, 52 p. (In Russian).

5. Berkov P. N. O bibliograficheskih trudah po russkoj periodicheskoj pechati: Vstupitel'naya stat'ya [On bibliographic works on Russian periodicals: Introductory article]. Mashkova M. V., Sokurova M. V. Obshchie bibliografii russkih periodicheskih izdanij 1703-1954 gg. i materialy po russkoj periodicheskoj pechati: Annotirovannyj ukazatel' [General bibliographies of Russian periodicals 1703-1954. and materials on Russian periodicals: Annotated index] Leningrad, [n. a.], 1956, pp. 5-34. (In Russian).

6. Varadinov N. V. Tridcatiletie "Zhurnala Ministerstva vnutrennih del" [Thirtieth Anniversary of the "Journal of the Ministry of Internal Affairs”]. St. Petersburg, [n. a.], 1859, 104 p. (In Russian).

7. Vatejshvili D. L. Gruziya i evropejskie strany: ocherki istorii vzaimootnoshenij, XIII-XIX vv. [Georgia and European countries: Essays on the history of mutual relations, 13th-19th centuries]: in 3 vols. Vol. 3: Gruziya i Rossiya, XVIII-XIX vv. [Georgia and Russia, 18th-19th centuries]: in 4 books. Book 3. Moscow, Ed. of the Institute of Russian History of the Russian Academy of Sciences, 2006, 775 p. (In Russian).

8. Vyderzhki iz druzheskih pisem Evgeniya (budushchego mitropolita Kievskogo) k voronezhskomu priyatelyu ego Vasiliyu Ignat'evichu Makedoncu [Excerpts from the friendly letters of Eugene (the future Metropolitan of Kiev) to his Voronezh friend Vasily Ignatyevich Makedonets]. Russkij Arhiv [Russian Archive], 1870, issue 4-5, pp. 769870. (In Russian).

9. Vyazemskij P. A. Pis'ma iz Parizha [Letters from Paris]. Polnoe Sobranie Sochinenij knyazya P. A. Vyazemskogo [Complete collection of works of Prince P. A. Vyazemsky]. Vol. 1. St. Petersburg, [n. a.], 1878, pp. 219-259. (In Russian).

10. Gillel'son M. I. Ukazatel' statej i drugih prozaicheskih proizvedenij P. A. Vyazemskogo s 1808 po 1837 gg. [Index of articles and other prose works of P. A. Vyazemsky from 1808 to 1837]. Uchenye zapiski Gor'kovskogo universiteta. Seriya istoriko-filologicheskaya [Scientific notes of the Gorky University. Historical and philological series]. Gorky, [n. a.], 1963, issue 58, pp. 113-332. (In Russian).

11. Gillel'son M. I. P. A. Vyazemskij — zhizn' i tvorchestvo [P. A. Vyazemsky-life and creativity] Leningrad, "Nauka" Publ., 1969, 391 p. (In Russian).

12. Gorobec A. F. Otechestvennye yuridicheskie zhurnaly XIX veka (evolyuciya i harakternye osobennosti) [Domestic legal journals of the 19th century (evolution and characteristic features)]: avtoref. dis.... cand. philol. sciences, Krasnodar, [n. a.], 2012, 27 p. (In Russian).

13. Gorobec A. F. Pervye yuridicheskie periodicheskie izdaniya zhurnal'nogo tipa [The first legal periodicals of the journal type]. Mir nauki, kul'tury, obrazovaniya [World of Science, Culture, and Education], 2020, no. 2 (81), pp. 604-606. (In Russian).

14. Dopolneniya i popravki k istorii russkih gazet i zhurnalov: Pis'mo k Izdatelyu "Telegrafa" [Additions and amendments to the history of Russian newspapers and magazines: A letter to the Publisher of "Telegraph"]. Moskovskij Telegraf [The Moscow Telegraph], 1928, Ch. XXIV, no. 22, pp. 225-235. (In Russian).

15. Zhurnal Ministerstva vnutrennih del [Journal of the Ministry of Internal Affairs], 1830, no. 1. (In Russian).

16. Ideologii i genezis cennostej sovremennogo obshchestva [Ideologies and the genesis of the values of modern society]. St. Petersburg, Ed. of the Russian Christian Humanitarian Academy, 2016, 352 p. (In Russian).

17. Istoriya russkoj zhurnalistiki XVIII-XIX vv. [History of Russian journalism of the 18 th-19 $9^{\text {th }}$ centuries] / ed. by A. V. Zapadov. Moscow, "High School” Publ., 1973, 521 p. (In Russian).

18. Kalendarova $V$. V. Vozniknovenie vedomstvennoj periodiki v Rossii v nachale XIX veka. Pervye ministerskie zhurnaly [The emergence of departmental periodicals in Russia at the beginning of the 19th century. First Ministerial journals]: autoref. dis... cand. hist. sciences. St. Petersburg, [n. a.], 2000, 26 p. (In Russian).

19. Kalendarova $V$. V. Liberal'nye idei v Rossii v nachale XIX veka: popytka pravitel'stvennoj propagandy (opyt kolichestvennogo analiza soderzhaniya pervyh ministerskih zhurnalov) [Liberal ideas in Russia at the beginning of the 19th century: an attempt at government propaganda (the experience of quantitative analysis of the content of the first ministerial journals)]. Istochnik. Istorik. Istoriya. Sbornik nauchnyh rabot [A source. The historian. History. Collection of scientific papers], issue 1, St. Petersburg, [n. a.], 2001, pp. 52-72. (In Russian).

20. Kanadzava T. Otzyvy o "Detskom muzeume" v gazete "Severnaya Pochta ili Novaya Sankt-Peterburgskaya gazeta" [Reviews of the "Children's Museum" in the newspaper "Northern Mail or New St. Petersburg newspaper"]. Tekstologiya i istoriko-literaturnyj process. V Mezhdunarodnaya konferenciya molodyh issledovatelej: sbornik statej [Textology and the historical and literary process. V International Conference of Young Researchers: collection of articles]. Moscow, "Buki-Vedi" Publ., 2017, pp. 48-57. (In Russian).

21. Krasnozhon O. V. Pechat' Ministerstva vnutrennih del kak sredstvo obespecheniya effektivnoj deyatel'nosti vedomstva (rezul'taty retrospektivnogo analiza) [The periodics of the Ministry of Internal Affairs as a means of ensuring the effective activity of the department (results of a retrospective analysis)]. Vestnik Sankt-Peterbugskogo universiteta MVD [Bulletin of the St. Petersburg University of the Ministry of Internal Affairs], 2017, no. 1 (73), pp. 23-27. (In Russian). 
22. Majkov L. N. Ocherki iz istorii russkoj literatury XVII i XVIII stoletij [Essays from the history of Russian literature of the 17th and 18th centuries]. St. Petersburg, [n. a.], 1889, 434 p. (In Russian).

23. Masanov I.F. Slovar' psevdonimov russkih pisatelej, uchenyh i obshchestvennyh deyatelej [Dictionary of pseudonyms of Russian writers, scientists and public figures]. St. Petersburg, "All-Union Book Chamber" Publ., 1956, vol. 1, 442 p. (In Russian).

24. Mysli grazhdanina [Thoughts of a citizen]. Sankt-Peterburgskij Zhurnal [St. Petersburg Journal], 1806, no. 1. pp. 95-98. (In Russian).

25. Nekotorye zamechaniya o podlozhnyh uvech'yah, $\mathrm{v}$ otbyvatel'stvo ot rekrutstva chinimyh [Some remarks on fake injuries, in serving out the recruitment]. Sankt-Peterburgskij Zhurnal [Saint-Petersburg Journal], 1804, no. 11, pp. 14-143. (In Russian).

26. O tyur'mah v Filadel'fii [About prisons in Philadelphia]. Sankt-Peterburgskij Zhurnal [Saint-Petersburg Journal], 1804, no. 10. pp. 115-139. (In Russian).

27. Obozrenie russkih gazet i zhurnalov s samogo nachala ih do 1828 goda [Review of Russian newspapers and magazines from their very beginning to 1828]. Moskovskij Telegraf [The Moscow Telegraph], 1827, Ch. XVIII, no. 23, pp. 123-148. (In Russian).

28. Obozrenie russkih gazet i zhurnalov... (prodolzhenie) [Review of Russian newspapers and magazines... (continued)]. Moskovskij Telegraf [The Moscow Telegraph], Ch. XVIII, no. 24, pp. 179-195. (In Russian).

29. Otdel rukopisej Rossijskoj Gosudarstvennoj Biblioteki [Department of Manuscripts of the Russian State Library]. Fond 233. S. D. Poltorackij [Fund 233. S. D. Poltorackij]. (in Russian, unpublished).

30. Pis'ma iz Peterburga v Italiyu grafa Zhozefa de Mestra [Letters from St. Petersburg to Italy by Count Joseph de Maistre]. Russkij Arhiv [Russian Archive], 1871, no. 6, pp. 53-149. (In Russian).

31. Predtechenskij A. V. Ekonomicheskie zhurnaly pervoj chetverti XIX v. [Economic journals of the first quarter of the 19th century]. Obshchestvennaya mysl' v Rossii XIX v. [Public thought in Russia of the 19th century]. Leningrad, "Nauka" Publ., 1985, pp. 7-18. (In Russian).

32. Primechaniya o prodazhe lyudej v rekruty [Notes on the sale of people in recruits]. Sankt-Peterburgskij Zhurnal [St. Petersburg Journal], 1804, no. 10, pp. 119-122 (In Russian).

33. Pypin A. N. Obshchestvennoe dvizhenie v Rossii pri Aleksandre I [Social movement in Russia under Alexander I]. Ed. 4-e. Petrograd., [n. a.], 1918, 587 p. (In Russian).

34. Rossijskij gosudarstvennyj istoricheskij arhiv (RGIA) [Russian State Historical Archive]. Fond 1286. Departament policii ispolnitel'noj [Fund 1286. Police Executive Department]. (in Russian, unpublished).

35. Sankt-Peterburgskie vedomosti, 1803, no. 92. (In Russian).

36. Sankt-Peterburgskie vedomosti, 1804, no. 95. (In Russian).

37. Sankt-Peterburgskie vedomosti, 1808, no. 53. (In Russian).

38. Sankt-Peterburgskie vedomosti, 1808, no. 66. (In Russian).

39. Sankt-Peterburgskie vedomosti, 1808, no. 95. (In Russian).

40. Sankt-Peterburgskij Zhurnal [Saint-Petersburg Journal], 1804, no. 12, p. 140. (In Russian).

41. Svedeniya, vypisannye iz rossijskih letopiscev [Information extracted from the Russian chroniclers]. SanktPeterburgskij zhurnal [Saint-Petersburg Journal], 1809, no. 5, pp. 63-84. (In Russian).

42. Severnaya Pochta ili Novaja Sankt-Peterburgskaja gazeta [Northern Mail New St. Petersburg Newspaper], 1819, no. 105. (In Russian).

43. Sonina E. S. N.M. Karamzin v "Severnoj pochte ili Novoj Sankt-Peterburgskoj gazette" [Karamzin in the "Northern Post or the New St. Petersburg Newspaper"]. Russkaya literatura i zhurnalistika v dvizhenii vremeni [Russian Literature and Journalism in the Movement of Time], 2018, no. 1, pp. 25-37. (In Russian).

44. Sonina E. S. "Skol' mozhno bolee svobody": "Severnaya Pochta, ili Novaya Sankt-Peterburgskaya gazeta" o cenzure ["How much more freedom is possible": "The Northern Post, or the New St. Petersburg Newspaper" about censorship]. Cenzura v Rossii: istoriya i sovremennost': Sbornik nauchnyh trudov [Censorship in Russia: history and modernity: a collection of scientific works]. St. Petersburg, [n. a.], 2017, pp. 359-371. (In Russian).

45. Stan'ko A. I. Stanovlenie teoreticheskih znanij o periodicheskoj pechati v Rossii (XVIII v. - 60-e gg. XIX v.) [Formation of theoretical knowledge about the periodical press in Russia (18th century - 60s of the 19th century)]. Rostov-on-Don, Rostov University Press, 1986, 206 p. (In Russian).

46. Ferebov A. N. K voprosu o hronologii svodnyh statisticheskih dannyh, opublikovannyh $\mathrm{v} 23$-em nomere "Periodicheskogo sochineniya o uspekhah narodnogo prosveshcheniya". Predvaritel'nye itogi issledovaniya [To the question of the chronology of summary statistical data published in the 23rd issue of the "Periodical Essay on the success of Public Education". Preliminary results of the study]. URL: https://moluch.ru/conf/hist/archive/ 54/2491. (accessed: 31.03.2021). (In Russian).

47. Shevcov $V$. $V$. Formirovanie i razvitie gubernskoj oficial'noj pressy Sibiri vo vtoroj polovine XIX - nachale XX veka [Formation and development of the provincial official press of Siberia in the second half of the 19th - early 20th century]: autoref. dis... d-r hist. sciences. Tomsk, [n. a.], 2014, 51 p. (In Russian).

48. Yanchenko I. L., Tokmacheva A. Yu. Vedomstvennaya periodicheskaya pechat' v sisteme Ministerstva vnutrennih del Rossijskoj imperii (doreformennyj period XIX v.) [Departmental periodical press in the system of the Ministry 
of Internal Affairs of the Russian Empire (pre-reform period of the 19th century)]. Trudy Akademii upravleniya MVD Rossii [Proceedings of the Academy of Management of the Ministry of Internal Affairs of Russia], 2018 , no. 4, pp. 86-92. (In Russian).

Received 23.09.2020

Kalendarova V. V., Candidate of History, Associate Professor at Department of History of Civilization, Physical Culture, Sports, Philosophy and Sociology

Russian State University of Physical Education, Sport, Youth and Tourism

Sirenevyj bul'var st., 4, Moscow, Russia, 105122

E-mail: vkalendarova@mail.ru 